\title{
ISLAMIC CHARACTERS EDUCATION CONSTRUCT OF YOUNG GENERATION BASED ON LOCAL CULTURAL VALUES OF LAMPUNG INDIGENOUS PEOPLES
}

\author{
Syaripuddin Basyar \\ Raden Intan State Islamic University of Lampung \\ Sukarame, Bandar Lampung, Lampung, Indonesia, 35131 \\ E-mail: basyarsyarif@yahoo.co.id

\section{Zulhanan} \\ Raden Intan State Islamic University of Lampung \\ Sukarame, Bandar Lampung, Lampung, Indonesia, 35131 \\ E-mail: zulhannan@radienintan.ac.id
}

\author{
Ahmad Muzakki \\ State Islamic Institute Metro \\ Iring Mulyo, West Metro, Metro, Lampung, 34112 \\ E-mail: ahmadmuzakki@metrouniv.ac.id
}

\begin{tabular}{|c|c|c|}
\hline Received & Revised & Approved \\
$17 / 12 / 2019$ & $13 / 06 / 2020$ & $30 / 07 / 2020$ \\
\hline
\end{tabular}

DOI: https:// doi.org/10.32332/akademika.v25i1.1739

\section{(c) (i) ()}

Islamic Characters Education Construct Of Young Generation Based On Local Cultural Values Of Lampung Indigenous Peoples Licensed Under a Creative Commons Attribution-ShareAlike 4.0 International License

\begin{abstract}
This paper describes the construct of Islamic character education based on the local culture of the indigenous Lampung people. Four constructs of character education are presented in the Piil Pesenggiri, namely Nemui Nyimah which contains the character of a sense of acceptance, including; hospitality, hospitality, generosity, courtesy, mutual respect, respect, love for friendship, submission and submission to the
\end{abstract}


Creator of the Universe and His creations. Nengah Nyappur contains adaptive character values in interacting, including; willingness to open up, have a high tolerance, like to deliberate, have an attitude and sociable behavior, easy to get along with, familiar or friendly, and a sense of family. Sakai Sambaiyan contains high solidarity character values, including; mutual assistance, please help, work together, give each other something that is needed by the other party. Juluk Adok contains the spirit of achievement character values, including; persistent and hard working, likes to participate, has an honorary degree. In the context of education, Piil Pesenggiri becomes an inseparable part of the realization of the nation's character education. Piil Pesenggiri becomes a principle of self-esteem which is the culmination and reflection of the accumulation of noble and noble forms of activity amid society. In the context of geneology education in the character of Lampung indigenous people, Piil Pesenggiri can be a measure or dignity for someone amid their life activities. Substantially, Piil Pesenggiri in the context of character education becomes the "pillar of the teacher" that teaches the principles of consistency, acceptance, and equality.

Keywords: character education, lampung cultural values, pesenggiri piil, and the philosophy of life of indigenous peoples

\section{A. Introduction}

The character education discourse has been widely studied by experts, for example, Lickona ${ }^{1}$, Megawangi ${ }^{2}$, Koesoema ${ }^{3}$, Handoyo and $\mathrm{Tijan}^{4}$, as well as many other researchers, practitioners, and academics - at home and abroad who discuss character education. In the Indonesian context, character education has a daunting task, namely reconstructing and restructuring the shifting of character values and moral degradation that is happening amid in the midst of the social environment of society.

${ }^{1} \mathrm{He}$ is one of the bearers of world character education. According to him, character education is the same as character education plus which involves three aspects, namely; knowledge (cognitive), feeling, and action. Look inside Thomas Lickona, Educating for Character: How Our Schools Can Teach Respect and Responsibility, (New York: Batam Books, 1991).

2 Ratna Megawangi, Semua Berakar pada Karakter: "Isu-isu Permasalahan Bangsa", (Jakarta: Fakultas Ekonomi Universitas Indonesia, 2007).

${ }^{3}$ Doni Koesoema A, Pendidikan Karakter: Strategi Mendidik Anak di Zaman global, (Jakarta: Grasindo, 2010).

4 Eko Handoyo dan Tijan, Model Pendidikan Karakter Berbasis Konservasi: Pengalaman Universitas Negeri Semarang, (Semarang: Widya Karya Press, 2010). 
So far, moral decadence is a common problem and difficult to overcome. The government has implemented character education through formal institutions, but this effort has not shown any indication of success. The existence of regulations in the form of Law Number 20 the year 2003 concerning the National Education System (National Education System) ${ }^{5}$, Ministry of Education Regulation Number 23 the year $2006^{6}$ and the basic framework of character values 7 in the national education curriculum have not yet succeeded in becoming a guide or character education management system. There are still many people who are mired in a moral "poverty gap". For example, the corrupt behavior of some of our political elitesboth at the national and local levels. ${ }^{8}$ Not only that, the behavior of

${ }^{5}$ Muhammad Guntur dan Aslinda, "Implementasi Kebijakan Pendidikan Karakter Terhadap Pengaruh Globalisasi," dalam Seminar Nasional "Pendidikan Ilmu-Ilmu Sosial Membentuk Karakter Bangsa Dalam Rangka Daya Saing Global," Makassar,: Fakultas Ilmu Sosial Universitas Negeri Makassar dan Himpunan Sarjana Pendidikan Ilmu-ilmu Sosial Indonesia, 2016), h. 233.

6 Minister of National Education Regulation No. 23/2006 Concerning Competency Standards Graduates explain that basic education (elementary and junior high) aims to provide the basis of intelligence, knowledge, personality, noble character, and skills as provisions for independent living and continuing education. One of the educational goals expressed in Permendikas No. 23 of 2006 above is personality / character. Personality / character education is important to be implemented to equip students to live independently and meet national education goals. Look inside Wisda Miftakhul Ulum, "The Development of Character-Based Intensive Reading Text Book in Elementary School," Jurnal Pendidikan Humaniora Vol. 2, no. 2 (16 Februari 2015): h. 131.

7 The values include; religious values, honesty, tolerance, discipline, hard work, creative, independent, democratic, curiosity, national spirit, love of the motherland, respect for communication, friendly/communicative, love peace, love to read, care for the environment, care for the social, and responsibility answer. Look inside Kementerian Pendidikan Nasional, Bahan Pelatihan Penguatan Metodelogi Pembelajaran Berdasarkan Nilai-Nilai Budaya Untuk Membentuk Daya Saing Dan Karakter Bangsa; Pengembangan Pendidikan Budaya Dan Karakter Bangsa, (Jakarta: Kementerian Pendidikan Nasional Badan Penelitian dan Pengembangan Pusat Kurikulum, 2010), h. 9.

8 Referring to the data released by Kompas Research and Development, 2004-2011; there are around 158 regional heads involved in corruption cases. While at other elite levels, between 2008-2011; there are around 42 DPR members who have fallen into the vortex of corruption. Meanwhile, in the period 1999-2004; around 30 DPR members were involved in a bribery dispute over the BI DGS election case. Not only up to here, corruption cases also investigated various state elite institutions, such as; KPU, KY, KPPU, Ditjend Pajak, BI and BKPM. See in Litbang Kompas, "Membangun Karakter Bangsa Melalui Pendidikan 
deviations of moral values and characters in other forms is also still often seen in various regions. Call it in Lampung, for example; student brawl, hijacking, theft, riots, and conflicts between ethnic groups ${ }^{9}-$ are often unavoidable.

The emergence of a variety of phenomena indicated Patimah as a sign or an indication of the failure of the implementation of character education

Berkarakter,"Www.Batararayamedia.Com (blog), November 26, 2011, http://www.batararayamedia.com/page.php?menu =artikel\&id=77\&title=Membangun-KarakterBangsa-Melalui-PendidikanBerkarakter.

9 Based on successful data the writer collects from a variety of events that override moral values and national character include; corruption, brutality, student brawl, and ethnic riots. In the corruption section; the writer can identify several officials at the level of the head of the department and regent who commit corruption. For example, the Corruption that occurred in the management of local revenue (PAD) funds from water sample testing levies at the UPT Environmental Laboratory Management Office of Lampung Province, valued at Rp 345 Million; more complete see in https://www. tribunnews.com/ regional/2017/09/11/. Then, the corruption committed by the former Head of the East Lampung Health Office, who asked the entire UPTD to deposit around $10 \%$ of the $2016 \mathrm{JKN}$ funds after the disbursement; See also http:/ / www.lampost.co/berita; Acts of corruption also befell the active regional head in Tanggamus Regency. The Bupati of these two periods is alleged to have bribed several Tanggamus DPRD members about the ratification of the 2016 Revenue and Expenditure Budget (APBD) for the fiscal year 2016. See in http://duajurai.co/2016/10/22/4/; The corruption case also befell the Head of the Bandar Lampung Health Office, who was allegedly involved in a corruption case of a medical equipment procurement budget worth Rp 9.9 billion. Look at https://nasional.tempo.co/ read/498675/. Meanwhile, in the case of student brawl, researchers succeeded in gathering data about student brawl occurred in Bandarlampung, between several students of SMA Nusa with SMK 2 May Bandarlampung, which occurred at Jalan Cut Mutia Bandarlampung, Thursday (10/24). Look at http://www.detiklampung.com/; Student brawl also occurred again in Bandarlampung, involving dozens of students from SMKN 3 and SMA 8 Bandarlampung, Tuesday (11/8/). The event started around 2:00 p.m. WIB, coinciding with the time after school. For more information, see http://harianlampung. com/index.php ?; Not only in Bandar Lampung, but student brawl also penetrated in Central Lampung Regency. The brawl between students took place at SMAN 1 Terbanggibesar, Central Lampung, Saturday, 6/8/2016. Look at http://inilampung.com/dipicu-ejekan-di-medsos-pelajar-dilampung-tengah-tawuran/ 
in Indonesia.10 Efforts to apply character education as "on the road"; stagnant; it can't even be "massively enjoyed". This reality underlies the birth of character education studies from various perspectives and approaches. In several practical implementation studies, there are many variations on the themes and topics of study, such as in the family, community, and formal education environment. ${ }^{11}$ In the formal scope (school), Ichsan proposed the need to reorganize character education. ${ }^{12}$ This is suspected Siswanto ${ }^{13}$, if the management of our education is still carried out partially; cognitive aspects and skills still dominate, while aspects of spiritual and emotional intelligence tend to be ruled out. As a result, the value output produced by education tends to be secular, materialistic, rationalistic, and hedonistic. At the very least, examining and rediscovering character education based on religious values needs to be done.

An interesting locus of character education studies is also seen in the social, cultural, and religious sectors. Some researchers show their belief that character education is the essence of Islam. Mudhofir explicitly said that the substance of Islamic teachings is character. So, to be able to shape personality and noble character, morals must be instilled in the souls of

10 Siti Patimah, "Formalisme Pendidikan Karakter Di Indonesia: Telaah Pendidikan Islam," Jurnal Pendidikan Islam 27, No. 1 (2012): h. 117, https://doi.org/10.15575/jpi.v27i1.499.

11 See inside, Priyo Sudibyo, "Manajemen Pendidikan Karakter TK BIAS Palangan Yogyakarta," EL TARBAWI Vol. 8, no. 2 (2015): 195-206, https://doi.org/10.20885/tarbawi.vol8.iss2.art6; see also in Sri Suyanta, "Membangun Pendidikan Karakter Dalam Masyarakat," Jurnal Ilmiah Islam Futura 13, no. 1 (August 1, 2013): 1-11, https://doi.org/10.22373/jiif.v13i1.568; See also in Ichsan Ichsan, "Menata Kembali Pendidikan Karakter Di Sekolah," Al-Bidayah: Jurnal Pendidikan Dasar Islam 3, no. 2 (2011), https://doi.org/10.14421/albidayah.v3i2.47; See also in Heldanita Heldanita and Suyadi Suyadi, "Pendidikan Karakter Anak Usia Dini:," Indonesian Journal of Islamic Early Childhood Education 3, no. 1 (2018): 123-38; Unang Wahidin, "Pendidikan Karakter Bagi Remaja," Edukasi Islami: Jurnal Pendidikan Islam 2, no. 03 (June 8, 2017), https://doi.org/10.30868/ei.v2i03.29; see also in I. Wayan Sutarwan, "Pendidikan Karakter Dan Moralitas Bagi Anak," Dharma Duta 15, no. 1 (2017), https:/ / doi.org/ 10.33363/dd.v15i1.291; see also in Ahmad Zainuri, "Pendidikan Karakter Di Masyarakat," Conciencia 19, no. 1 (June 30, 2019): 1-9, https://doi.org/10.19109/conciencia.v19i1. 2644.

12 Ichsan, "Menata Kembali Pendidikan Karakter Di Sekolah."

13 Siswanto, "Pendidikan Karakter Berbasis Nilai-Nilai Religius," TADRIS: Jurnal Pendidikan Islam 8, no. 1 (January 2, 2014): h. 92-107, https://doi.org/10.19105/jpi.v8i1.385. 
children. ${ }^{14}$ Mukhid in his article also described the Prophet as a node and display of the majesty and nobility of the Qur'an. The character and personality values that exist in the Prophet, "must" be instilled in children from an early age. ${ }^{15}$ Not to forget, Marjuni also emphasized that the values of Islamic education are solid pillars for character education. ${ }^{16}$ While Kurniawan ${ }^{17}$ while referring to al-Ghazali's thinking, recommending the implementation of character education must be based on moral values. From an Islamic perspective, character education is very basic and substantive. Akhlakul karimah or "mandatory" character education is instilled in children from an early age so that noble, tough, and noble characteristics and personalities emerge.

Furthermore, in the context of multicultural societies ${ }^{18}$, character education is urgently applied..$^{19}$ Character education is very substantial and fundamental in psychological processes. ${ }^{20}$ The existence of character education can help a person in developing thought patterns, attitudes, and behaviors to become a positive, virtuous, noble, and responsible person..$^{21}$ Character education has become an important part that is inseparable from

14 Ali Mudlofir, "Pendidikan Karakter: Konsep Dan Aktualisasinya Dalam Sistem Pendidikan Islam," Nadwa, Vol. 7, no. 2 (22 Maret 2016): 229-46, https://doi.org/10.21580/nw.2013.7.2.560.

15 Abd Mukhid, "Konsep Pendidikan Karakter Dalam Al-Qur'an," NUANSA: Jurnal Penelitian Ilmu Sosial dan Keagamaan Islam, Vol. 13, no. 2 (31 Desember 2016): 309-28, https://doi.org/10.19105/nuansa.v13i2.1102.

16 Marjuni Marjuni, "Pilar-Pilar Pendidikan Karakter Dalam Konteks Keislaman," AULADUNA: Jurnal Pendidikan Dasar Islam 2, no. 1 (1 Juni 2015): 15469.

17 Syamsul Kurniawan, "Pendidikan Karakter Dalam Islam Pemikiran AlGhazali Tentang Pendidikan Karakter Anak Berbasis Akhlaq al-Karimah," Tadrib, Vol. 3, no. 2 (2017): 197-216, https:/ / doi.org/10.19109/Tadrib.v3i2.1792.

18 Hadi Machmud, "Pendidikan Nilai Karakter Berbasis Multikultural,"

Shautut Tarbiyah, Vol. 17, no. 2 (1 November 2011): 57-70, https://doi.org/10.31332/str.v17i2.148.

19 Mohammad Kosim, "Urgensi Pendidikan Karakter," KARSA: Journal of Social and Islamic Culture 19, no. 1 (22 Februari 2012): 91, https://doi.org/10.19105/karsa.v19i1.78.

${ }^{20}$ Mangun Budiyanto and Imam Machali, "Pembentukan Karakter Mandiri Melalui Pendidikan Agriculture Di Pondok Pesantren Islamic Studies Center Aswaja Lintang Songo Piyungan Bantul Yogyakarta," Jurnal Pendidikan Karakter, Vol. IV, No.2, (June 2014): h. 110.

21 Yasin Nurfalah, "Urgensi Nilai-Nilai Pendidikan Karakter," Jurnal Pemikiran Keislaman 27, no. 1 (5 Januari 2016): 186, https://doi.org/10.33367/tribakti.v27i1.264. 
the life cycle of humanity. In the education chain, character values are obliged to run and continue from time to time-without pause, without questioning space, place, and conditions - so that they can apply from and to the next generation. Formally the contribution of education in building the character of society is highly expected. But unfortunately, our education world is not maximally able to do much to provide outputs to the formation of character education of its students. ${ }^{22}$ Maybe there needs to be adjusted in terms of philosophical, regulatory, practice, system, to the resources that manage it.

Some researchers have exposed and recommended the superiority of local wisdom as a product of the local culture that can be used as a basic framework or reference to moral values and character. Priyatna shows the noble values of local wisdom is the character identity of the community. Because it is considered not in accordance with the times, these values are set aside ${ }^{23}$, and even become a forgotten national character education. ${ }^{24}$ Sahlan mentioned actually, the application of local wisdom values can collaborate in the development of character education in schools. The condition is that teachers must play an active role in using these values as learning material..$^{25}$ Such practices do not run optimally, because, in the learning process in the classroom, conventional methods and old learning patterns still dominate. ${ }^{26}$ The practice and process of character education will never succeed without involving all components; stakeholders, and including education components; starting from the contents of the

22 Deny Setiawan, "Peran Pendidikan Karakter Dalam Mengembangkan Kecerdasan Moral," Jurnal Pendidikan Karakter, Tahun III, no. 01, (Februari 2013): h. 54.

23 Muhammad Priyatna, "Pendidikan Karakter Berbasis Kearifan Lokal," Edukasi Islami: Jurnal Pendidikan Islam Vol. 5, no. 10 (25 Oktober 2017): 1311-36, https://doi.org/10.30868/ei.v5i10.6.

24 Zuhairansyah Arifin, "Pendidikan Berbasis Budi Pekerti: Menguak Karakter Pendidikan Bangsa yang Terlupakan," Kutubkhanah, Vol. 15, no. 1 (2012): 94-103.

25 Sahlan, "Kearifan Lokal Pada Kabanti Masyarakat Buton Dan Relevansinya Dengan Pendidikan Karakter," el Harakah, Vol. 14, no. 2 (26 Juni 2013): 312-25, https://doi.org/10.18860/ el.v14i2.2311.

26 For example, there are still many teachers using a teacher centered approach, expository dominance, intellectual-oriented learning, cognitive-oriented evaluation, and the teacher's position as a transfer of knowledge - a fact that shows how strong conventional learning dominance is. More complete see inside Deny Setiawan, "Peran Pendidikan Karakter Dalam Mengembangkan Kecerdasan Moral," Jurnal Pendidikan Karakter Tahun III, no. 1 (18 Maret 2013): h. 55, https://doi.org/ 10.21831/ jpk.v0i1.1287. 
curriculum to the work ethic issues of all citizens and the school environment. ${ }^{27}$ It's not simple, character education is a job that must involve upstream and downstream education. ${ }^{28}$ In this section, the position of local wisdom with its noble values found in almost all corners of this country has the potential opportunity to be used as a basic framework or reference of moral values in overcoming the "chaotic" condition of our character education world. Once again, the prerequisite that must be met is to be brave and confident in promoting the existence of local wisdom in each region.

To borrow the term Hasanah, in the Lampung context-it is not impossible and there is an opportunity for it - if the indigenous people who still exist and maintain their local wisdom are an inseparable part of the development of character education. ${ }^{29}$ Lampung indigenous people have the values of local wisdom Piil Pesenggiri; which consists of four pillars, namely; Nemui Nyimah, Nengah Nyappur, Sakai Sambaiyan, and Juluk Adok. Substantially, these noble values can be used as a blueprint for character education and harmony education for the people. ${ }^{30}$ The transmission of these noble values will be more easily distributed to the younger generation because the elders and traditional leaders have their own classifications ${ }^{31}$ in carrying out and carrying out their duties. In the structural circulation spectrum of the traditional system, the traditional elders continue to maintain, care for, and preserve the local cultural values they have. Not only that, but traditional leaders can also play a role model or role model for their communities.

${ }^{27}$ Kosim, “Urgensi Pendidikan Karakter,” 91.

28 Ani Cahyadi, "Menguatkan Indonesia: Revitalisasi Pembelajaran Pendidikan Karakter," Analisis: Jurnal Studi Keislaman, Vol. 14, no. 2 (2014): h. 371, https://doi.org/10.24042/ajsk.v14i2.695.

29 Aan Hasanah, "Pengembangan Pendidikan Karakter Berbasis Kearifan Lokal Pada Masyarakat Minoritas (Studi atas Kearifan Lokal Masyarakat Adat Suku Baduy Banten)," Jurnal Analisis, Vol.XII, no. No. 1 (Juni 2012): h. 212.

${ }^{30}$ Ahmad Muzakki, "Introducing Local Genius-Based Harmony Education (Piil Pesenggiri) Among The Indigenous People Of Lampung," Jurnal PENAMAS, Vol. 30, no. 3, (Oktober-Desember 2017).

31 Adapun tingkatan tokoh adat atau yang biasa disebut pemimpin adat, meliputi: (1) Penyimbang Mega (Merga); (2) Penyimbang Tiuh (tingkat kampong); (3) Penyimbang Suku; (4) Penyimbang adat; (5) Penyimbang Tuwa. Lebih lengkap lihat dalam Abu Tholib Khalik, Pelatoeran Sepandjang Hadat Lampong: Deskripsi dan Terjemahan Hukum Adat Migou Pak Tulangbawang, (Yogyakarta: Badan Penerbitan Filsafat UGM, 2010), h. 27-28. 
Responding to the explanation above, and given that formally our education world has not been able to do much in shaping the character education of its students, this article attempts to describe the construct of education of young generation's local wisdom based on the local wisdom values of the Lampung indigenous people. Indirectly, this argument shows the improvisation of character education must not only be done in one direction and focused on cognitive and academic areas only, but through a variety of ways; multi-site, multi-domain, and cross-level. Also Besides, character education needs to be actualized integrally and comprehensively in all fields and layers. Space character education needs to be widened; not solely dominated by formal territory, but must be space and time at the non-formal and informal level. Through the values of existing local wisdom, the transformation and internalization of values will be cohesive and become a strong character for the community.

\section{B. Local Cultural Values and Character Representation of Lampung Indigenous People}

The success of the ancestors of the Lampung indigenous people produced treasures of local values in the form of a philosophy of life called Piil Pesenggiri. Piil Pesenggiri becomes a reflection and representation of the ethics and characteristics of the Lampung indigenous people. For generations, Piil Pesenggiri is a formulation that manifests as a source of knowledge and cultural capital to "guide" the community in carrying out life activities in a multicultural society. For the Lampung indigenous people, the values of the Piil Pesenggiri are used as a philosophy of life and dignity. Someone can not or can not be said to have self-esteem if they have not implemented the elements or components of the Piil Pesenggiri itself. This relates to the identity and identity of the indigenous people of Lampung. So, the philosophical meaning must animate all aspects, creativity, and life activities of the people of Lampung. ${ }^{32}$

Historically, Piil Pesenggiri came from the laws of the Lampung community, namely the Book of Kuntara Rajaniti, Cepalo, and Keterem.33 In a meaningful way, Piil is interpreted as behavior, while Pesenggiri means high morale, big soul, self-knowledge, knowing rights, and obligations. Piil Pesenggiri is also interpreted as a source of motivation for everyone to be

32 Himyari Yusuf, "Nilai-Nilai Islam Dalam Falsafah Hidup Masyarakat Lampung," Kalam: Jurnal Studi Agama dan Pemikiran Islam, Vol. 10, no. 1, (Juni 2016): h. 170.

${ }^{33}$ Lasiyo and A. Fauzie Nurdin, "Budaya Muakhi Dan Pembangunan Daerah: Perspektif Filsafat Sosial Pada Komunitas Adat Pubian Di Lampung," Jurnal Penelitian Agama, Vol. XVII, no. No. 3 (December 2008): h. 633. 
able to act or behave dynamically to fight for values; positive, live with dignity, and be respected amid community life. ${ }^{34}$ Thus, Piil Pesenggiri is everything that concerns self-esteem, behavior, and life attitudes that can maintain and uphold the good name of giving something that is needed for other parties and it is not limited to something that is material, but also in a moral sense. including thought contributions and so on.

In almost all aspects and scope of life of the indigenous Lampung people (read; Ulun Lampung), Piil Pesenggiri is the basic value and pillar. This is evident from the ritual of birth to death. ${ }^{35}$ Piil Pesenggiri was transformed as a source of inspiration and a "magnetic field" in all forms of creativity and life activities of the people of Lampung. ${ }^{36}$ Besides, Piil Pesenggiri is also synonymous with deeds or human behavior that has a depth of meaning and value. Indirectly, the essence of Piil Pesenggiri's philosophy of life constitutes display or an overall, comprehensive, and holistic picture of human beings. From this, it will appear the identity or identity of the people of Lampung, if those aspects are inherent and can be internalized in every dimension of creativity and life activities of the people of Lampung. ${ }^{37}$

In the context of the plurality of Lampung Province residents-Piil Pesenggiri which is supported by its main pillars, such as; Pesenggiri (abstinence), Juluk Adek (like with a good name or honorable title), Nemui Nyimah (likes to receive and give), Nengah Nyappur (likes to get along and consult), and Sakai Sambaiyan (likes to help and work hand in hand) ${ }^{38}$-able to deal with - with the multicultural situation of the people. Not only that, but Piil Pesenggiri can also be used as a medium for harmony ${ }^{39}$ education amid diversity. Therefore, studying Piil Pesenggiri as well as dialoguing and

34 Simon Sumanjoyo Hutagalung, "Adopsi Nilai Kearifan Lokal Dalam Kinerja Kepolisan Daerah Provinsi Lampung," Publisia: Jurnal Ilmu Administrasi Publik 3, no. 1 (April 1, 2018): h. 34, https://doi.org/ 10.26905/pjiap.v3i1.1923.

35 Sulistyowati Irianto dan Risma Margaretha, "Piil Pesenggiri: Modal Budaya Dan Strategi Identitas Lampung," Makara Sosial Humaniora, Vol. 15, no. 2, (2011): h. 142.

${ }^{36}$ Himyari Yusuf, "Dimensi Aksiologis Filsafat Hidup Piil Pesenggiri Dan Relevansinya Terhadap Pengembangan Kebudayaan Daerah Lampung," Jurnal Filsafat, Vol. 20, No. 3, (Desember 2010): h. 282.

${ }^{37}$ Yusuf, "Nilai-Nilai Islam Dalam Falsafah Hidup Masyarakat Lampung," h. $169-170$.

38 Hilman Hadikusuma, Masyarakat dan Adat-Budaya Lampung, Cet. I (Bandung: Mandar Maju, 1990), h. 15.

39 Muzakki, "Introducing Local Genius-Based Harmony Education (Piil Pesenggiri) Among The Indigenous People Of Lampung,." 
discussing character education based on local cultural values. Therefore, the development of character education will be influenced by the existing environment. By its locus, in every struggle and plural society struggle, Piil Pesenggiri can appear as a form of cultural independence and way of life for the indigenous people of Lampung. The five pillars will support the identity and identity of the people. In this position, Piil Pesenggiri can be used as a foundation in anticipating the emergence of a variety of moral degradation and community character. As Siswanto said, et al., That the embodiment of the values contained in the philosophical points of life is a pattern of life that is good in principle and is the basic norm of the indigenous people of Lampung. ${ }^{40}$

Noting this description -Hobsbawm ${ }^{41}$ has warned all components of the nation to properly review and reflect again, then to rediscovery, revitalize-even to do some sort of invented tradition of the nation's sublime cultural values through the national movement by involving all existing components, thus giving birth to a consensus of national awareness. It is indeed hard, but some efforts and strategies that can be used to anticipate it, namely by reexamining the premises and old cultural values through forms of education. ${ }^{42}$ Since civilization struggled with the global system, character education for the younger generation is considered important to be reapplied. Character education becomes a necessity to be considered seriously. Because, this has become a crucial phenomenon and has become a form of special challenges for the realization of qualified, superior, and noble personality of Indonesian people. In this context, the Lampung traditional community has had cultural capital in the form of local cultural values which are reflected in the philosophy of life of Piil Pesenggiri to shape the characteristics and personality of the community.

\section{Piil Pesenggiri: Spirit and Values of Lampung Indigenous Character Education}

Amid the complexities of changing times, Piil Pesenggiri as the capital and cultural values of indigenous peoples -will directly intersect with shifts and changes in civilization connected to the global system. The

40 Edi Siswanto, Astim Riyanto, dan Prayoga Bestari, “Pelestarian Budaya Piil Pesinggiri Dalam Masyarakat Mulitikutural Lampung Serta Pengaruh Globalisasi Ditinjau Dari Aspek Kajian Pendidikan Kewarganegaraan," Jurnal Civicus, Vol 18, no. 2 (2014): h. 144.

${ }^{41}$ E.J. Hobsbawm dan T.O. Ranger, ed., The Invention of Tradition, (New York: Cambridge University Press, 1983).

42 Handoyo dan Tijan, Model Pendidikan Karakter Berbasis Konservasi: Pengalaman Universitas Negeri Semarang, h. 3. 
values that exist in the five pillars of the Piil Pesenggiri may be contaminated by the uproar of the times. Conscious or not, the character education contained therein will be reduced to its noble values. This is very possible-considering the intensity and scope of globalization has touched almost every aspect of life. Not only in the fields of economics, business, politics, ideology, culture-it has even entered certain spaces, such as systems, processes, actors, and events. ${ }^{43}$ The meeting of the two poles namely face to face between Piil Pesenggiri with changes in civilization connected in the global system - is not impossible. Finally, this process will have an impact on people's lives and give birth to many opportunities as well as challenges ${ }^{4}$ in them. If so, it would need an effort and concrete action from all levels of society to anticipate the emergence of attitudes and characteristics that deviate from the nation's personality.

As we all know, that the character of a nation is built from core ethical values that are rooted in religious values, state philosophy and culture. ${ }^{45}$ Thus, if the manifestation of a character refers to the manifestation of a series of attitudes, behaviors, motivations and skills ${ }^{46}$, then the philosophy of life of Piil Senggiri has great opportunities and potential in the process of building a nation's civilization that is strong and resilient. Conceptually, the basic framework of character education in Lampung's indigenous people stems from the collectivity of customs, traditions and cultural values that have been implemented for a long time. Essentially, the Piil Penggenggiri is a noble, great and noble human behavior, character and character in its value and meaning. ${ }^{47}$ Therefore, the Piil Pesenggiri should be carried out or implemented and never be denied or denied.

In another dimension, Piil Pesenggiri becomes a form or form of selfesteem and an attitude of life that must be accompanied by maintaining and upholding the name both personally and in groups. That is, overall Piil Pesenggiri has a very noble meaning, that is, having a big heart, having a

${ }^{43}$ Jan Pronk, "Globalization: A Developmental Approach.," in Global Futures, Shaping Globalization, ed. Jan Nederveen Pieterse, (London: Zed Books, 2001), h. 43.

44 Walter Leimgruber, Between Global and Local, (England: Ashgate Publishing Limited, 2004), h. 18.

45 Muhammad Priyatna, "Pendidikan Karakter Berbasis Kearifan Lokal," Edukasi Islami: Jurnal Pendidikan Islam 5, no. 10 (October 25, 2017): h. 1312, https://doi.org/10.30868/ ei.v 5i10.6.

${ }^{46}$ Lian G. Otaya, "Pendidikan Karakter Berbasis Nilai," Nadwa 8, no. 1 (19 April 2014): h. 78, https://doi.org/10.21580/ nw.2014.8.1.571.

47 Yusuf, "Nilai-Nilai Islam Dalam Falsafah Hidup Masyarakat Lampung," h. 169. 
sense of shame, friendly, sociable and please help. 48 In their daily lives, the Lampung traditional community has principles that show the originality of its population which is accumulated in five major principles. ${ }^{49}$ The desire to live parallel and be able to coexist with anyone is reflected in his Piil Pesenggiri. Ulun Lappung does not want to be at the top or live at the top, while others are at the bottom. And conversely, they do not want their lives to be down, if others are above.50 Overall, these values represent the concepts of equality and equality in the lives of humanity. Everyone must be able to be useful to others, not use others. When someone violates the principles of the Piil Pesenggiri, this is the same as doing something taboo. Upholding and safeguarding the Piil Pesenggiri is something that is ingrained in Lampung's indigenous people. ${ }^{51}$

\section{Juluk Adek: Display of Noble Character}

In the Lampung traditional community, every baby born is given a good name by both parents. However, the baby was also given a "Juluk" (read; Juluk - small title) from his grandfather. After being mature and married, they will use "adek", which is an old title obtained through a ceremony conducted in the presence of family leaders and or traditional elders. ${ }^{52}$ According to Syani, Juluk Adek is an inherent right for members of the Lampung community, as well as being the main identity attached to the person concerned. ${ }^{53}$ Several variants appear in the writing Juluk Adok, such as; Juluk Adek, and Bejuluk Buadok. The terminology does not reduce the substance of the inherent meaning.

Juluk Adek is an identity that must be properly maintained and maintained by the indigenous people of Lampung. The Juluk Adek is very important, because it has a connection with one's efforts to be able to

48 Camelia Arni Minandar, "Aktualisasi Piil Pesenggiri Sebagai Falsafah Hidup Mahasiswa Lampung Di Tanah Rantau," SOSIETAS Vol. 8, no. 2 (2018): h. 518, https://doi.org/10.17509/sosietas. v8i2.14594.

49 Lasiyo and Nurdin, "Budaya Muakhi Dan Pembangunan Daerah: Perspektif Filsafat Sosial Pada Komunitas Adat Pubian Di Lampung," h. 633.

50 Yusuf, "Nilai-Nilai Islam Dalam Falsafah Hidup Masyarakat Lampung," h. 170.

51 Fathu Sururi, "Mak Di Juk Siang Pada Masyarakat Adat Lampung Pepadun Megou Pak," AL-HUKAMA: The Indonesian Journal of Islamic Family Law, Vol. 06, no. 01, (Juni 2016): h. 134.

52 Hadikusuma, Masyarakat dan Adat-Budaya Lampung, h. 120.

53 Abdul Syani, "Abdul Syani: Implementasi Nilai-Nilai Piil Pesenggiri Dalam Membangun Kemandirian Desa*," Abdul Syani (blog), 25 November 2018, http://abdulsyani.blogspot.com/2018/ 11/implementasi-nilai-nilai-piil.html. 
position the rights and obligations, words and actions in each of his behavior and work. In other terms, the Adjudicator is a display of nobility of character and responsibility from someone. Every person who is given a good identity will have good character values as well. However, not all people who already have a Juluk Adek can or can represent it properly. As said by one of the traditional leaders of Megou, Pak Tulangbawang, Abu Tholib Khalik, that every title (Juluk Adek) owned by indigenous people, does not guarantee that they will be able to apply it during the community. ${ }^{54}$ The title should be accompanied by the establishment of someone. Well-established here is not only interpreted as material power alone, but the person is truly able to apply and internalize other noble characters implied and written in the philosophy of life Piil Pesenggiri. Juluk Adek attached to someone must be accompanied by struggle or sacrifice in upgrading self-perfection, orderly life, and good manners. ${ }^{55}$ Indirectly, the two figures illustrate if Juluk Adek is a display or reflection of the nobility of someone's character that appears from an identity that is attached to someone.

Degree (Adek) can not be obtained easily by everyone, so he must go through cycles, conditions and heavy stages. At the very least, the person can achieve or get a glorious achievement-both for the community in general and in adat. After this cycle can be passed, then according to Fachrudin there must be a legality to commemorate the awarding of a customary title (Adek). ${ }^{56}$ Noting this, the identity that is inherent in every person must be accompanied by the concept of self-perfection, having etiquette, adhering to the Titie Gematie of Lampung custom.

\section{E. Nemui Nyimah: Value of Character Education of Social Concern and Loving Each Other}

For the Lampung traditional community, Nemui Nyimah is one of the pillars of character education which implies mutual respect between people. Nemu means accepting guests or visiting other people. While Nyimah is interpreted as a form of giving something to a guest, or a member of a relative of his acquaintance as a sign of remembering, a

${ }^{54}$ Wawancara dengan salah satu tokoh adat Megou Pak Tulang Bawang, Bapak Abu Thalib Khalik Gelar Tuan Gusti Adat.

${ }^{55}$ Wawancara dengan salah satu tokoh adat Buay Nuban, Humaidi El Hudri bergelar Suttan Kanjeng Sunan Agung

56 Fachruddin, Upacara Cangget Agung Aktualisasi Nilai-Nilai Budaya Daerah Lampung Bagi Generasi Muda, (Lampung: Departemen Pendidikan dan Kebudayaan Kanwil Propinsi Lampung, 1998), h. 21. 
familiar sign..$^{57}$ Indirectly, the literal meaning implicit in the concept of Nemui Nyimah are forms of attitude and character of mutual respect and respect for others.

These attitudes are not only aimed at fellow adat members, but must also be done to other people (read; migrants) in Lampung Province. In other words, concerning the reality around us, there is a need to be respectful and polite.58 If judging by using Law Number 20 the year 2003 Regarding the National Education System ${ }^{59}$-especially Chapter 3 of the National Education System Law - then Nemui Nyimah is one of the conceptions of character education that has strong and urgent reasons to internalize and apply in the community.

Through this conception, a person or indigenous Lampung community is expected to have an attitude of social care and high human values. Also, the values of Nemui Nyimah will lead one to have a broad and progressive outlook going forward. These principles and attitudes can be addressed and shown to any guests who come, as long as they have sincere, good intentions and are willing to develop and advance the Lampung region, they must be respected and respected. ${ }^{60}$ When a person can realize it in the context of a multicultural community life, then the concrete form of life of Nemui Nyimah's philosophy will create a harmonious community environment and help one another. ${ }^{61}$ The rediscovery of these values will further strengthen the character and social capital of the community in communicating broadly. So far, the communication aspect is seen as a channel and entrance to create a harmonious society. ${ }^{62}$

57 Hadikusuma, Masyarakat dan Adat-Budaya Lampung, h. 121.

58 Yusuf, "Dimensi Aksiologis Filsafat Hidup Piil Pesenggiri Dan Relevansinya Terhadap Pengembangan Kebudayaan Daerah Lampung," h. 283.

59 "National education functions to develop capabilities and shape the nation's character and civilization with dignity in the context of educating the life of the nation, aiming at developing the potential of students to become human beings who believe in and fear God Almighty, have noble, healthy, knowledgeable, capable, creative, be independent, and be a democratic and responsible citizen. "

${ }^{60}$ Wawancara dengan Humaidi El-Hudri, Hidayat Sanjaya, M. Shihabudin

61 Shely Cathrin, "Piil Pesenggiri Sebagai Landasan Hidup Orang Lampung Relevansinya Dengan Pengembangan Karakter Bangsa Indonesia," Seminar Nasional KeIndonesiaan II Tahun 2017, Strategi Kebudayaan dan Tantangan Ketahanan Nasional Kontemporer, 2017, h. 252.

62 Muzakki, "Introducing Local Genius-Based Harmony Education (Piil Pesenggiri) Among The Indigenous People Of Lampung," h. 271. 


\section{F. Nengah Nyappur: Character Values Want to Accept and Appreciate Differences}

Lampung Region has a pluralistic and multicultural society. Noting the diversity that exists, Lampung indigenous people already have cultural capital to carry out social processes and interactions with each other. Nengah Nyappur is the third pillar that can function as a foundation for the character education of the indigenous people of Lampung. If judging from the origin of the word, Nengah means to the middle or meant to hang out and Nyappur means to mix or interact with other people. ${ }^{63}$ According to Sarbini and Khalik, Nengah; is in the middle (audience), and Nyappur means to mingle. Nengah Nyappur is also interpreted as a pattern of community life, not isolating themselves from people or tribes, or other nations. ${ }^{64}$ Then Nengah Nyappur contains tolerance character values. This character is very important for the community to create a harmonious life. The values of tolerance character contained in Nengah Nyappur can be a "wasilah" or a connecting road for other people in daily interactions. On the other hand, if the tolerance character values can be implemented well, it will be able to minimize conflicts or disputes that often occur.

The explanation above shows that Nengah Nyappur is a form of existence in interacting from the Lampung indigenous community. It is illustrated that Nengah Nyappur has the same value, which is to prioritize or prioritize the high sense of family and friendship. Interact with anyoneindigenous people do not prioritize ethnic, religious and group egos. According to Young and Raymond as quoted by Soekanto ${ }^{65}$ that in all social life a password is needed to carry it out, namely social interaction. Based on this abstraction, Nengah Nyappur which is a form of manifestation of noble values and personalities, should be used as character education values for the community in carrying out relationship relationships in a multicultural society.

The value of tolerance character education in the context of multicultural life becomes an oasis to create harmony. If only these characters can be seriously internalized in all cross forums. If this can happen it will have an impact on the formation of strong characters and personalities, to create dynamism during society. Therefore, a sincere understanding, continuous application of the concept of Nengah Nyappur,

63 Hadikusuma, Masyarakat dan Adat-Budaya Lampung, h. 122.

${ }^{64}$ Abdurrahman Sarbini dan Abu Tholib Khalik, Budaya Lampung: Versi Adat Megou Pa' Tulangbawang, (Yogyakarta: Badan Penerbitan Filsafat UGM, 2010), h. 32.

65 Soerjono Soekanto, Sosiologi Suatu Pengantar, (Jakarta: PT. RajaGrafindo Persada, 2006), h. 61. 
will be able to create a harmonious bond or social fabric with a spirit of mutual respect and respect.

\section{G. Sakai Sambaian: High Charity and Social Character Characteristic}

One of the characters possessed by the Lampung indigenous people is the nature of Sakai Sambaian. This trait is a form of one's obligation to have a social spirit, mutual assistance, do good to others, in return for services or not. ${ }^{66}$ From this it can be seen if Sakai Sambaian character values in the form of manifestations or outputs from real actions and high social forms of social life of the indigenous people of Lampung. Not only that, Sakai Sambaian, also took the form of an accommodative attitude towards input and the ability to provide constructive or constructive criticism. So it is often interpreted as a style of cooperation (cooperative) which is parallel and egalitarian, as a working partner rather than as a superior with subordinates or can be called a symbiotic relationship of mutualism, namely mutual benefit in the good.67 Therefore, ideally Sakai Sambaian who has an applicative nature must be practiced by someone.

Based on the above factors, the inherent and identical character in Sakai Sambaian is the spirit of cooperation of the indigenous people of Lampung. This is in line with the literal meaning that "Sakai/Sesakai" means please help one after another and "Sambaian/Sesambayan" means to work together in groups in doing something heavy. ${ }^{68}$ The tradition or character of petrification and cooperation have been inherent in the indigenous Lampung community. This action is not only limited to matters or issues of Lampung custom, but broader than that. The form of help is not limited to mere material aspects, but also in the form of moral aspects; such as the contribution of thought, motivation and others. Therefore, Sakai Sambaian means the character of please help and cooperation, so that its existence shows a sense of participation and high solidarity towards various personal and social activities in general.

In its context, the existence of Piil Pesenggiri is supported by several other important components, namely; Juluk Adek, Nemui Nyimah, Nengah Nyappur, and Sakai Sambaian. As explained earlier, that each component has its character value. Next, the writer identifies the character values contained in the Piil Pesenggiri and its reinforcing components.

${ }^{66}$ Sarbini dan Khalik, Budaya Lampung: Versi Adat Megou Pa' Tulangbawang, h. 33 .

${ }^{67}$ Fachruddin, Upacara Cangget Agung Aktualisasi Nilai-Nilai Budaya Daerah Lampung Bagi Generasi Muda, h. 19-20.

${ }^{68}$ Hadikusuma, Masyarakat dan Adat-Budaya Lampung, h. 123. 
Table of Piil Pesenggiri Character Values

\begin{tabular}{|c|l|}
\hline $\begin{array}{c}\text { Local Culture/Local } \\
\text { Wisdom }\end{array}$ & \multicolumn{1}{c|}{$\begin{array}{c}\text { Description of Character Values } \\
\text { contained }\end{array}$} \\
\hline Piil Pesenggiri & $\begin{array}{l}\text { Pride; have a shameful nature, maintain a } \\
\text { personal or collective good name }\end{array}$ \\
\hline Juluk Adek & $\begin{array}{l}\text { Spirit of achievement; include persistent } \\
\text { and hard-working, likes to participate, has } \\
\text { an honorary degree. }\end{array}$ \\
\hline Nemui Nyimah & $\begin{array}{l}\text { Sense of Acceptance; including hospitality, } \\
\text { hospitality, generosity, courtesy, mutual } \\
\text { respect, respect, fond of friendship, } \\
\text { submission, and submission to the Creator } \\
\text { of the Universe and His creations. }\end{array}$ \\
\hline Nengah Nyappur & $\begin{array}{l}\text { Adaptive in interacting; include willingness } \\
\text { to open oneself, have a high tolerance, like } \\
\text { to deliberate, have an attitude and sociable } \\
\text { behavior, easy to get along with, familiar or } \\
\text { friendly, a sense of family. }\end{array}$ \\
\hline Sakai Sambaian & $\begin{array}{l}\text { High solidarity; in the form of mutual } \\
\text { assistance, please help, work together, give } \\
\text { each other something that is needed by the } \\
\text { other party }\end{array}$ \\
\hline
\end{tabular}

Based on the above table, Piil Pesenggiri has a lot of character values that can be implemented to the younger generation, especially the indigenous people of Lampung. These character values are not contradictory to the 18 character characters set by the Ministry of National Education. Hilman explained, that in the philosophy of living Piil Pesenggiri contained cultural values of work, namely productive values (Nemui Nyimah); competitive values (Nengah Nyappur); cooperative values (Sakai Sambaiyan); and contains innovative values (Juluk Adek).69 This Piil Pesenggiri has become the principle and attitude of life of the Lampung indigenous community which is at the same time a standard of honor for humans as a custom. Achieving this requires strong character values, strong and not easily give up. As Suttan Melinting said, that the younger generation to foster a strong attitude, strong soul and identity to change the conditions or conditions of life to be better; such as serious attitude,

${ }^{69}$ Hadikusuma, h. 119-123. 
tenacious, diligent and willing to search carefully and thoroughly when studying and studying religion. ${ }^{70}$

In the context of self-improvement and floating (upgrading) the capacity and potential of a person, the characteristic value of Piil Pesenggiri is a necessity to be applied. In this position, this type of character becomes a form of self-motivation to take actions or actions that lead to the benefit of life for others. In other words, this type of character is a behavior or a kind of penance which must be taken by someone to deconstruct or reformulate themselves to be better than others. From these behaviors produce products that are of benefit and benefit to the lives of humankind, and not instead set a bad precedent or can even lead to disaster for others.

In building character education for the younger generation, Lampung traditional leaders have a very large contribution in making it happen. The position of traditional leaders in a community has a high "selling power" to be the captain in disseminating the values of character education based on local culture. According to Humaidi Elhudri ${ }^{71}$, through his role in the community, traditional leaders have the freedom to spread it. This effort cannot be done "half-heartedly" because it will affect the goal (goal). Then the efforts and efforts must also be carried out consciously, planned, thoroughly and comprehensively.

The contribution made by traditional leaders in spreading the values of Lampung's local culture-based character education is carried out through the education process in the family and community. As Suttan Melinting 72 said, the authority is not relevant to the law or regulation of the state, but it still informs the values of character education based on local culture to its indigenous people. He continues to campaign for Piil Pesenggiri as the philosophy of life of indigenous peoples that contains the value of character education. His seriousness in disseminating customary information is evidence of the responsibilities and mandates he carries as Suttan. As a king and a public figure, he does not want his citizens to lose the characteristic values of their culture. "I always talk to them about new insights. I also told them to pay attention to the development of information. I also communicate and monitor Melinting people who are currently on overseas". 73

70 Rizal Ismail, Suttan Melinting dari Keratuan Melinting Kabupaten Lampung Timur, Wawancara dilakukan pada tanggal 4 Mei 2019

${ }^{71}$ Humaidi Elhudri, wawancara

72 Rizal Ismal atau Suttan Melinting, Wawancara

${ }^{73}$ Rizal Ismail atau Suttan Melinting, Wawancara 
To maintain the values of local wisdom and culture, Suttan Melinting also forms a form of collaboration with other Lampung traditional leaders. He made a campaign movement how important local wisdom and customary law are for the community. Not only that, to be legal, he also sought the support of various parties to encourage customary law to be made into a regional regulation (Perda) by the regional government. The emergence of this idea was motivated by the problem of diminishing and decreasing understanding and implementation of the Lampung indigenous people about their customs and culture. ${ }^{74}$

Some Lampung traditional leaders have endeavored to make a "back to local wisdom" movement. They have a local policy that aims to counteract the depletion of character education values based on local culture. Together with other traditional leaders, they encourage customs or customary laws to be realized in their respective regional regulations (Perda). The intent and purpose is that customary rules are more grounded to indigenous peoples. Community activeness in customary activities can divert people's attention towards the emergence and development of movements that increasingly characterize the position, position and role of culture, national customs. Through a campaign against local culture, which is highly expected, people will increasingly love, love their culture and customs. On another aspect, local traditions or what are then familiar as local geniuses can be used as a form of characteristics of their citizens, so that they can become a "shield" for society from the influence of foreign cultures that are not by national identity.

\section{H. Conclusion}

Based on the description above, it can be concluded that the construct of character education in Lampung's young generation is presented in the values of their local culture which has been used as a philosophy of life, namely Piil Pesenggiri. Within the cultural values of these indigenous peoples there are four constructs of the value of character education that are useful for sustaining a person who can be said to have Piil Pesenggiri. Nemui Nyimah is a construct of character education about a sense of acceptance which includes hospitality, hospitality, generosity, courtesy, mutual respect, respect, love and friendship, submission and submission to the Creator of the Universe and His creations. Nengah Nyappur is a construct of character education about adaptive in interacting, including willingness to open up, have a high tolerance, like to talk, have attitudes and sociable behavior, easy to get along, familiar or friendly, and a sense of

${ }^{74}$ Rizal Ismail atau Suttan Melinting, Wawancara 
family. Sakai Sambaiyan is a construct of character education about high solidarity which includes cooperation, please help, work together, give each other something that is needed by the other party. And, Juluk Adok is a construct of character education about the spirit of achievement which includes persistent character and diligent work, likes to participate, has an honorary degree. The four constructs of character education if implemented in everyday life, it will foster one's self-esteem[.]

\section{REFERENCES}

Arifin, Zuhairansyah. "Pendidikan Berbasis Budi Pekerti: Menguak Karakter Pendidikan Bangsa yang Terlupakan,." Kutubkhanah, Vol. 15, no. 1 (2012): 94-103.

Budiyanto, Mangun, dan Imam Machali. "Pembentukan Karakter Mandiri

Melalui Pendidikan Agriculture di Pondok Pesantren Islamic

Studies Center Aswaja Lintang Songo Piyungan Bantul Yogyakarta,." Jurnal Pendidikan Karakter, IV, no. No.2 (Juni 2014).

Cahyadi, Ani. "Menguatkan Indonesia: Revitalisasi Pembelajaran Pendidikan Karakter,." Analisis: Jurnal Studi Keislaman, Vol. 14, no. 2 (2014): 357-74. https://doi.org/10.24042/ ajsk.v14i2.695.

Cathrin, Shely. "Piil Pesenggiri Sebagai Landasan Hidup Orang Lampung Relevansinya Dengan Pengembangan Karakter Bangsa Indonesia,." Seminar Nasional KeIndonesiaan II Tahun 2017, Strategi Kebudayaan dan Tantangan Ketahanan Nasional Kontemporer, 2017.

Doni Koesoema A. Pendidikan Karakter: Strategi Mendidik Anak di Zaman global,. Jakarta: Grasindo, 2010.

Fachruddin. Upacara Cangget Agung Aktualisasi Nilai-Nilai Budaya Daerah Lampung Bagi Generasi Muda,. Lampung: Departemen Pendidikan dan Kebudayaan Kanwil Propinsi Lampung, 1998.

Guntur, Muhammad, dan Aslinda. "Implementasi Kebijakan Pendidikan Karakter Terhadap Pengaruh Globalisasi,." Dalam Seminar Nasional. Makassar,: Fakultas Ilmu Sosial Universitas Negeri Makassar dan Himpunan Sarjana Pendidikan Ilmu-ilmu Sosial Indonesia, 2016.

Hadikusuma, Hilman. Masyarakat dan Adat-Budaya Lampung,. Cet. I. Bandung: Mandar Maju, 1990.

Handoyo, Eko, dan Tijan. Model Pendidikan Karakter Berbasis Konservasi: Pengalaman Universitas Negeri Semarang, Semarang: Widya Karya Press, 2010.

Hasanah, Aan. "Pengembangan Pendidikan Karakter Berbasis Kearifan Lokal Pada Masyarakat Minoritas (Studi atas Kearifan Lokal 
Masyarakat Adat Suku Baduy Banten),." Jurnal Analisis, Vol.XII, no. No. 1 (Juni 2012).

Heldanita, Heldanita, dan Suyadi Suyadi. "Pendidikan Karakter Anak Usia

Dini:" Indonesian Journal of Islamic Early Childhood Education 3, no. 1 (2018): 123-38.

Hobsbawm, E.J., dan T.O. Ranger, ed. The Invention of Tradition,. New York: Cambridge University Press, 1983.

Hutagalung, Simon Sumanjoyo, dan Tulfah H. Al Halim. “Adopsi Nilai Kearifan Lokal Dalam Kinerja Kepolisan Daerah Provinsi Lampung." Publisia: Jurnal Ilmu Administrasi Publik Vol. 3, no. 1 (1 April 2018): 45-52-52.https://doi. org/10.26905/pjiap.v3i1.1923.

Ichsan, Ichsan. "Menata Kembali Pendidikan Karakter Di Sekolah." Al-

Bidayah: Jurnal Pendidikan Dasar Islam Vol. 3, no. 2 (2011).https:// doi.org/10.14421 / al-bidayah.v3i2.47.

Irianto, Sulistyowati, dan Risma Margaretha. "Piil Pesenggiri: Modal Budaya Dan Strategi Identitas Lampung,." Makara Sosial Humaniora, Vol. 15, no. 2, (2011).

Kementerian Pendidikan Nasional. Bahan Pelatihan Penguatan Metodelogi Pembelajaran Berdasarkan Nilai-Nilai Budaya Untuk Membentuk Daya Saing Dan Karakter Bangsa; Pengembangan Pendidikan Budaya Dan Karakter Bangsa,. Jakarta: Kementerian Pendidikan Nasional Badan Penelitian dan Pengembangan Pusat Kurikulum, 2010.

Khalik, Abu Tholib. Pelatoeran Sepandjang Hadat Lampong: Deskripsi dan Terjemahan Hukum Adat Migou Pak Tulangbawang,. Yogyakarta: Badan Penerbitan Filsafat UGM, 2010.

Kosim, Mohammad. "Urgensi Pendidikan Karakter,." KARSA: Journal of Social and Islamic Culture 19, no. 1 (22 Februari 2012): 8492.https:// doi.org/10. 19105/karsa.v19i1.78.

Kurniawan, Syamsul. "Pendidikan Karakter Dalam Islam Pemikiran AlGhazali Tentang Pendidikan Karakter Anak Berbasis Akhlaq alKarimah,." Tadrib, Vol. 3, no. 2 (2017): 197-216. https:// doi.org/10.19109/Tadrib.v3i2.1792.

Lasiyo, dan A. Fauzie Nurdin. "Budaya Muakhi Dan Pembangunan Daerah: Perspektif Filsafat Sosial pada Komunitas Adat Pubian di Lampung,." Jurnal Penelitian Agama, Vol. XVII, no. No. 3 (September 2008).

Lickona, Thomas. Educating for Character: How Our Schools Can Teach Respect and Responsibility,. New York: Batam Books, 1991.

Litbang Kompas. "Membangun Karakter Bangsa Melalui Pendidikan Berkarakter." www.batararayamedia. com (blog), 26 November 2011.http://www.batara 
rayamedia.com/page.php?menu=artikel\&id=77\&title=Membangun -KarakterBangsa-Melalui-Pendidikan -Berkarakter.

Machmud, Hadi. "Pendidikan Nilai Karakter Berbasis Multikultural,."

Shautut Tarbiyah, Vol. 17, no. 2 (1 November 2011): 57-70. https:// doi.org/10.31332/str.v17i2.148.

Marjuni, Marjuni. "Pilar-Pilar Pendidikan Karakter Dalam Konteks Keislaman,." AULADUNA: Jurnal Pendidikan Dasar Islam 2, no. 1 (1 Juni 2015): 154-63.

Megawangi, Ratna. Semua Berakar pada Karakter: "Isu-isu Permasalahan Bangsa",. Jakarta: Fakultas Ekonomi Universitas Indonesia, 2007.

Minandar, Camelia Arni. "Aktualisasi Piil Pesenggiri Sebagai Falsafah Hidup Mahasiswa Lampung Di Tanah Rantau." SOSIETAS Vol. 8, no. 2 (2018). https://doi.org/10.17509/sosietas. v8i2.14594.

Mudlofir, Ali. "Pendidikan Karakter: Konsep Dan Aktualisasinya Dalam Sistem Pendidikan Islam." Nadwa, Vol. 7, no. 2 (22 Maret 2016): 22946. https://doi.org/10.21580/nw. 2013.7.2.560.

Mukhid, Abd. "Konsep Pendidikan Karakter Dalam Al-Qur'an,." NUANSA: Jurnal Penelitian Ilmu Sosial dan Keagamaan Islam, Vol. 13, no. 2 (31 Desember 2016): 309-28. https://doi.org/10.19105/ nuansa.v13i2.1102.

Muzakki, Ahmad. "Introducing Local Genius-Based Harmony Education (Piil Pesenggiri) Among The Indigenous People Of Lampung,." Jurnal PENAMAS, Vol. 30, no. 3, (Oktober-Desember 2017).

Nurfalah, Yasin. "Urgensi Nilai-Nilai Pendidikan Karakter,." Jurnal Pemikiran Keislaman 27, no. 1 (5 Januari 2016): 170 187-170 187. https:// doi.org/10.33367/tribakti.v27i1.264.

Otaya, Lian G. "Pendidikan Karakter Berbasis Nilai." Nadwa 8, no. 1 (19 April 2014): 75-94. https://doi.org/10.21580/nw.2014.8.1.571.

Patimah, Siti. "Formalisme Pendidikan Karakter Di Indonesia: Telaah Pendidikan Islam,." Jurnal Pendidikan Islam 27, no. 1 (2012): 115-27. https:// doi.org/10.15575/jpi.v27i1.499.

Priyatna, Muhammad. "Pendidikan Karakter Berbasis Kearifan Lokal,." Edukasi Islami: Jurnal Pendidikan Islam Vol. 5, no. 10 (25 Oktober 2017): 1311-36. https:/ / doi.org/10.30868/ ei.v5i10.6.

Pronk, Jan. "Globalization: A Developmental Approach." Dalam Global Futures, Shaping Globalization, disunting oleh Jan Nederveen Pieterse. London: Zed Books, 2001.

Sahlan. "Kearifan Lokal Pada Kabanti Masyarakat Buton Dan Relevansinya Dengan Pendidikan Karakter,." el Harakah, Vol. 14, no. 2 (26 Juni 2013): 312-25. https:// doi.org/10.18860/ el.v14i2.2311. 
Sarbini, Abdurrahman, dan Abu Tholib Khalik. Budaya Lampung: Versi Adat Megou $\mathrm{Pa}^{\prime}$ Tulangbawang, Yogyakarta: Badan Penerbitan Filsafat UGM, 2010.

Setiawan, Deny. "Peran Pendidikan Karakter Dalam Mengembangkan Kecerdasan Moral,." Jurnal Pendidikan Karakter, Tahun III, no. 01, (Februari 2013).

- - - . "Peran Pendidikan Karakter Dalam Mengembangkan Kecerdasan Moral,." Jurnal Pendidikan Karakter Tahun III, no. 1 (18 Maret 2013). https:// doi.org/10.21831/jpk. v0i1.1287.

Siswanto. "Pendidikan Karakter Berbasis Nilai-Nilai Religius,." TADRIS: Jurnal Pendidikan Islam 8, no. 1 (2 Januari 2014): 91107.https:// doi.org/ 10.19105/jpi.v8i1.385.

Siswanto, Edi, Astim Riyanto, dan Prayoga Bestari. "Pelestarian Budaya Piil Pesinggiri Dalam Masyarakat Mulitikutural Lampung Serta Pengaruh Globalisasi Ditinjau Dari Aspek Kajian Pendidikan Kewarganegaraan,." Jurnal Civicus, Vol 18, no. 2 (2014).

Soekanto, Soerjono. Sosiologi Suatu Pengantar,. Jakarta: PT. RajaGrafindo Persada, 2006.

Sudibyo, Priyo. "Manajemen Pendidikan Karakter TK BIAS Palangan Yogyakarta,." EL TARBAWI Vol. 8, no. 2 (2015): 195-206. https:// doi.org/10.20885/ tarbawi.vol8.iss2. art6.

Sururi, Fathu. "Mak Di Juk Siang Pada Masyarakat Adat Lampung Pepadun Megou Pak,." AL-HUKAMA: The Indonesian Journal of Islamic Family Law, Vol. 06, no. 01, (Juni 2016).

Sutarwan, I. wayan. "Pendidikan Karakter Dan Moralitas Bagi Anak,." Dharma Duta 15, no. 1 (2017). https:// doi.org/10.33363/dd.v15i1.291.

Suyanta, Sri. "Membangun Pendidikan Karakter Dalam Masyarakat,." Jurnal Ilmiah Islam Futura 13, no. 1 (1 Agustus 2013): 1-11. https:// doi.org/10.22373/ jiif.v13i1.568.

Syani, Abdul. "Abdul Syani: Implementasi Nilai-Nilai Piil Pesenggiri Dalam Membangun Kemandirian Desa*." Abdul Syani (blog), 25 November 2018. http://abdulsyani.blogspot.com/2018/11/ implementasi-nilai-nilai-piil.html.

Ulum, Wisda Miftakhul. "The Development of Character-Based Intensive Reading Text Book in Elementary School." Jurnal Pendidikan Humaniora Vol. 2, no. 2 (16 Februari 2015): 130-43.

Wahidin, Unang. "Pendidikan Karakter Bagi Remaja,." Edukasi Islami: Jurnal Pendidikan Islam 2, no. 03 (8 Juni 2017). https:// doi.org/10.30868/ ei.v2i03.29. 
Walter Leimgruber. Between Global and Local,. England: Ashgate Publishing Limited, 2004.

Yusuf, Himyari. "Dimensi Aksiologis Filsafat Hidup Piil Pesenggiri Dan Relevansinya Terhadap Pengembangan Kebudayaan Daerah Lampung,". Jurnal Filsafat, Vol. 20, no. 3, (Desember 2010).

- - - "Nilai-Nilai Islam Dalam Falsafah Hidup Masyarakat Lampung,." Kalam: Jurnal Studi Agama dan Pemikiran Islam, Vol. 10, no. 1, (Juni 2016).

Zainuri, Ahmad. "Pendidikan Karakter Di Masyarakat,." Conciencia 19, no. $1 \quad$ (30 Juni 2019): https:// doi.org/10.19109/conciencia.v19i1.2644. 
90 |AKADEMIKA, Vol. 25, No. 01 Januari-Juni 2020 